\title{
Influence of COVID-19 Event on Air Quality and their Association in Mainland China
}

\author{
Qi-Xiang Chen, Chun-Lin Huang, Yuan Yuan*, He-Ping Tan \\ School of Energy Science and Engineering, Harbin Institute of Technology, Harbin 150001, China
}

\begin{abstract}
The outbreak of 2019 novel coronavirus (COVID-19) has hugely impacted the world and becomes a global public threat. To prevent the spread of COVID-19, human activities are largely restricted in China in early February, 2020. The influence of strict COVID-19 control policies on air quality and the potential influence of particulate matter concentration on COVID-19 infection in China are of great interest. This study analyzes the concentrations of six major air pollutants in 366 urban areas across mainland China during January 1 to April 30 in 2017-2020. Results show that strict COVID-19 control policies have significantly improved the air quality in many provinces. Compared to 2019 , national mean concentrations of $\mathrm{PM}_{2.5}, \mathrm{PM}_{10}$, $\mathrm{SO}_{2}, \mathrm{NO}_{2}$ and $\mathrm{CO}$ in 2020 decrease by $14 \%, 15 \%, 12 \%, 16 \%$ and $12 \%$, respectively, while the concentration of $\mathrm{O}_{3}$ increases by $9 \%$. Generally, the diurnal variation of $\mathrm{PM}_{2.5}$ and $\mathrm{PM}_{10}$ concentrations remains unchanged during COVID-19 and their concentrations are high in the morning and evening while low in the afternoon. Correlation analysis shows that daily COVID19 infections are positively correlated with $\mathrm{PM}_{2.5}$ concentration in many provinces, indicating a potential risk of aerosol transmission in high $\mathrm{PM}_{2.5}$ environment. Thus it is suggested to stay at home in highly polluted days and go out in the afternoon to reduce the risk of infection due to aerosol transmission.
\end{abstract}

Keywords: COVID-19; Air quality; $\mathrm{PM}_{2.5}$; China.

\section{INTRODUCTION}

A novel and contagious pneumonia broke out in the late of 2019. Then it has been identified as a novel strain of coronavirus, which belongs to the same virus family of acute respiratory syndrome (SARS) and Middle East respiratory syndrome (MERS) (Zheng et al., 2020). This novel coronavirus is named as 2019 novel coronavirus (2019-nCoV) in January 13 and then as coronavirus disease 2019 (COVID-19) in March 6 by World Health Organization (WHO). From early medical reports in middle January, COVID-19 can be transmitted from human to human (Guo et al., 2020; Shereen et al., 2020). In China, the government immediately takes nationwide contingency plans to shut down the traffic and public activities and almost everyone is isolated at home. On June 5, 2020, over 6450000 confirmed cases and over 382000 death are reported by the National Health Commission around the world.

Air pollution is one of the major concerns around the world, especially in developing countries like China and India (Dong et al., 2019). Severe air pollution is a major health risk and can lead to large premature mortality (Schraufnagel

\footnotetext{
* Corresponding author.

E-mail address: yuanyuan83@ hit.edu.cn
}

et al., 2019). Previous studies have shown that $\mathrm{PM}_{2.5}$ has an adverse impact on human health and long-term exposure to high $\mathrm{PM}_{2.5}$ concentration environment will lead to various respiratory diseases because $-\mathrm{PM}_{2.5}$ carries lots of harmful matters and viruses and can go directly into our lungs (Hayes et al., 2019; McGuinn et al., 2019). As reported in the $6^{\text {th }}$ Edition of COVID-19 Treatment Regimen (Trial Implementation) published by the National Health Commission of the People's Republic of China, COVID-19 is mainly transmitted by direct contact and droplet transmission, and aerosol transmission is also a potential way (Wang and Du, 2020). The strict COVID-19 control measures implemented in China in the beginning of February aim to minimize the social contact to stop the spread of COVID-19 and results show that these control measures work very well (Kraemer et al., 2020). For example, Xu et al. (2020a) investigated the impact of COVID-19 epidemic prevention and control actions on air quality of three cities in Hubei province and found that the average concentrations of $\mathrm{PM}_{2.5}, \mathrm{PM}_{10}, \mathrm{SO}_{2}$, $\mathrm{CO}$ and $\mathrm{NO}_{2}$ in February 2020 were much lower than those in February 2017-2019 with an average reduction of 30.1\%, $40.5 \%, 33.4 \%, 27.9 \%$ and $61.4 \%$, respectively. A similar decrease was also reported in Anqing, Hefei, and Suzhou in February 2020 and the overall decreases for $\mathrm{PM}_{2.5}, \mathrm{PM}_{10}$, $\mathrm{SO}_{2}, \mathrm{CO}$ and $\mathrm{NO}_{2}$ are $46.5 \%, 48.9 \%, 52.5 \%, 36.2 \%$ and $52.8 \%$, respectively compared to those in the same month in 2017-2019 (Xu et al., 2020b). To understand the influence 
of strict control policy on air quality, it is necessary to gain a full view of how much improvement is made on air quality by these COVID-19 control measures across China. Also, current studies have shown that COVID-19 transmission is associated with temperature and humidity (Ma et al., 2020; $\mathrm{Xie}$ and Zhu, 2020), however, the potential influence of $\mathrm{PM}_{2.5}$ on COVID-19 is still not clear and it might be important for policy makers to implement proper measures to limit the spread of COVID-19 due to aerosol transmission.

In this study, the concentration of six major air pollutions $\left(\mathrm{PM}_{2.5}, \mathrm{PM}_{10}, \mathrm{SO}_{2}, \mathrm{NO}_{2}, \mathrm{CO}\right.$ and $\left.\mathrm{O}_{3}\right)$ measured in 366 urban areas in mainland China during COVID-19 is compared to previous years. The diurnal variations of particulate matter in 31 provinces during February to April are then analyzed. We also explores the potential correlation between $\mathrm{PM}_{2.5}$ concentrations and COVID-19 infections and give some suggestions to the public to minimize the risk of COVID-19 infections due to aerosol transmission.

\section{DATA AND METHODS}

\section{Data Collection}

In this study, a total number of 366 urban area in mainland China is used for the comparison of air quality. The air quality data used here are the hourly concentrations of $\mathrm{PM}_{2.5}$, $\mathrm{PM}_{10}, \mathrm{SO}_{2}, \mathrm{NO}_{2}, \mathrm{CO}$ and $\mathrm{O}_{3}$ as well as air quality index (AQI). The AQI is a dimensionless index describing the air quality (the lower the better). It is the maximum of sub-AQI of the above-mentioned six major pollutants (Eqs. (1) and (2)). The daily AQI is calculated from the 24-hour average of $\mathrm{PM}_{2.5}, \mathrm{PM}_{10}, \mathrm{SO}_{2}, \mathrm{NO}_{2}, \mathrm{CO}$, and the daily maximum 8hour $\mathrm{O}_{3}$ (Xu et al., 2020a). All these data can be obtained from China's National Environmental Monitoring Center (http://www.cnemc.cn). The time range of the air quality data is from January to April in 2017 to 2020.

$$
S A Q I_{P}=\frac{I_{\text {high }}-I_{\text {low }}}{C_{\text {high }}-C_{\text {low }}}\left(C_{p}-C_{\text {low }}\right)+I_{\text {low }}
$$

$A Q I=\max \left(S A Q I_{1}, S A Q I_{2}, \ldots, S A Q I_{p}\right)$

where $S A Q I_{p}$ represents the sub-AQI; $C_{p}$ denotes the concentration of pollutant $\mathrm{p} ; C_{\text {low }}$ and $C_{\text {high }}$ are the concentration breakpoints lower and higher than $C_{p}$, respectively; $I_{l o w}$ and $I_{\text {high }}$ are the index breakpoint corresponding to $C_{\text {low }}$ and $C_{\text {high }}$, respectively.

The daily counts of confirmed COVID-19 cases in all these 366 urban areas across mainland China are collected from an open Github project called Wuhan-2019-nCov, which provides the uptodate COVID-19 statistics across the world. The data is crawled from official reports and detailed information and COVID-19 data can be found at https://github.com/canghailan/Wuhan-2019-nCoV/blob/mas ter/Wuhan-2019-nCoV.json. The time range of the COVID19 data is same as the air quality data.

\section{Statistical Analysis}

A decrease ratio is defined as $\mathrm{DR}=1-\mathrm{X}_{2020} / \mathrm{X}_{2019}$, where
$\mathrm{X}$ denotes the average concentration of air pollutant and the subscript represents the year. And this ratio shows the degree of major pollutant reduction due to COVID-19 control policies.

The relationship between daily COVID-19 infections and particulate matter concentration may exhibit spatial variation due to changing aerosol source, control policy and other factors. To represent the varying COVID-19-PM relationship, we use a mixed effects model to analyze the influence of PM concentration on COVID-19 infections. The mixed effects model estimates daily COVID-19 infections for each site $i$ of day $j\left(\mathrm{COVID}_{i, j}\right)$ from corresponding PM concentration $\left(\mathrm{PM}_{i, j}\right)$ in the form of

$$
\begin{aligned}
& \log \left(\operatorname{COVID}_{i, j}\right)=\left(\alpha+\mu_{i}\right)+\left(\beta+v_{i}\right) \overline{P M}_{i, j}+\varepsilon_{i . j}, \\
& \left(\mu_{k} v_{k}\right) \sim N[(00), \Sigma]
\end{aligned}
$$

$\overline{P M}_{i, j}=\frac{P M_{i, j}-\text { mena }(P M)}{s d(P M)}$

where $\alpha$ and $\beta$ are the fixed intercept and slope independent of time and location, and $\mu_{\mathrm{i}}$ and $\mathrm{v}_{\mathrm{i}}$ are the random intercept and slope for each site. The random terms $\left(\mu_{i}\right.$ and $\left.v_{i}\right)$ are sites term which reflects the spatial difference of the COVID-19-PM relationship due to differences in site specific characteristics like aerosol sources, topography, population density, meteorology, etc. $\overline{P M}_{i, j}$ is the scaled PM concentration, and mean(PM) and sd(PM) represents the overall mean PM and its standard deviation. $\varepsilon_{\mathrm{i}, \mathrm{j}}$ and $\sum$ denote the error term and the variance-covariance matrix for the day-specific random effects. Only matchups with daily COVID-19 infection number $\geq 1$ are included in this mixed effect model analysis and the total number of matchups during the studying period is 4351 .

\section{RESULTS AND DISCUSSION}

\section{Site-scale Analysis of Air Pollutants}

Table 1 shows the ambient air quality standard from the Ministry of Ecology and Environment of the People's Republic of China (MEE) and the World Health Organization (WHO). The MEE Level I standard is designed for natural reserve and tourist attractions and Level II is for industrial, residence and rural areas. In general, WHO standards for $24 \mathrm{~h}$ average $\mathrm{PM}_{2.5}\left(25 \mu \mathrm{g} \mathrm{m}^{-3}\right), \mathrm{SO}_{2}\left(20 \mu \mathrm{g} \mathrm{m}^{-3}\right)$, and $\mathrm{NO}_{2}\left(40 \mu \mathrm{g} \mathrm{m}^{-3}\right)$ are lower than MEE Level I standards $\left(35 \mu \mathrm{g} \mathrm{m}^{-3}, 50 \mu \mathrm{g} \mathrm{m}^{-3}\right.$, and $\left.80 \mu \mathrm{g} \mathrm{m}^{-3}\right)$. The MEE Level I standards for $24 \mathrm{~h}$ average $\mathrm{PM}_{10}\left(50 \mu \mathrm{g} \mathrm{m}^{-3}\right)$ and $\mathrm{O}_{3}\left(100 \mu \mathrm{g} \mathrm{m}^{-3}\right)$ are in consistent with WHO standards.

Fig. 1 shows the site-scale concentrations of six major pollutants in February 2017-2019 and February 2020. For $24 \mathrm{~h}$ average $\mathrm{PM}_{2.5}$ and $\mathrm{PM}_{10}$, only the cities in Tibet and Yunnan as well as some northern cities in Heilongjiang meet the WHO and MEE Level I standard in February 20172019, and due to the strict control policy in February 2020, many cities in south China meet the standards and the spatial 
Table 1. Ambient air quality standard from the World Health Organization (WHO) and the Ministry of Ecology and Environment of the People's Republic of China (MEE).

\begin{tabular}{|c|c|c|c|c|c|c|}
\hline \multirow{2}{*}{ Pollutants } & \multicolumn{2}{|c|}{ WHO } & \multicolumn{3}{|c|}{ MEE } & \multirow{2}{*}{ unit } \\
\hline & Time range & Value & Time range & Level I & Level II & \\
\hline $\mathrm{PM}_{2.5}$ & $24 \mathrm{~h}$ & 25 & $24 \mathrm{~h}$ & 35 & 75 & $\mu \mathrm{g} \mathrm{m}^{-3}$ \\
\hline $\mathrm{PM}_{10}$ & $24 \mathrm{~h}$ & 50 & $24 \mathrm{~h}$ & 50 & 150 & $\mu \mathrm{g} \mathrm{m}^{-3}$ \\
\hline $\mathrm{SO}_{2}$ & $24 \mathrm{~h}$ & $20(7.6)$ & $24 \mathrm{~h}$ & $50(18.9)$ & $150(56.8)$ & $\mu \mathrm{g} \mathrm{m}^{-3}(\mathrm{ppb})$ \\
\hline $\mathrm{NO}_{2}$ & 1 year & $40(21.1)$ & $24 \mathrm{~h}$ & $80(42.3)$ & $80(42.2)$ & $\mu \mathrm{g} \mathrm{m}^{-3}(\mathrm{ppb})$ \\
\hline $\mathrm{O}_{3}$ & $8 \mathrm{~h}$ & $100(50.5)$ & $8 \mathrm{~h}$ & $100(50.5)$ & $160(80.8)$ & $\mu \mathrm{g} \mathrm{m}^{-3}(\mathrm{ppb})$ \\
\hline $\mathrm{CO}$ & - & - & $24 \mathrm{~h}$ & $4(3.5)$ & $4(3.5)$ & $\mathrm{mg} \mathrm{m}^{-3}(\mathrm{ppm})$ \\
\hline
\end{tabular}

Note: concentration $(\mathrm{ppb})=24.45 \div$ Molecular weight $\times$ concentration $\left(\mu \mathrm{g} \mathrm{m}^{-3}\right)$; concentration $(\mathrm{ppm})=24.45 \div$

Molecular weight $\times$ concentration $\left(\mathrm{mg} \mathrm{m}^{-3}\right)$; concentration with unit of ppb or ppm is shown in the parenthesis.

Level I is for natural reserve and tourist attractions. Level II is for industrial, residence and rural areas.

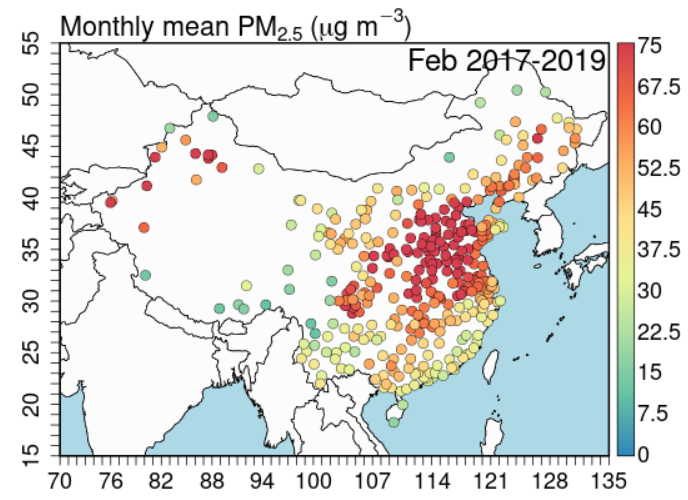

(a)

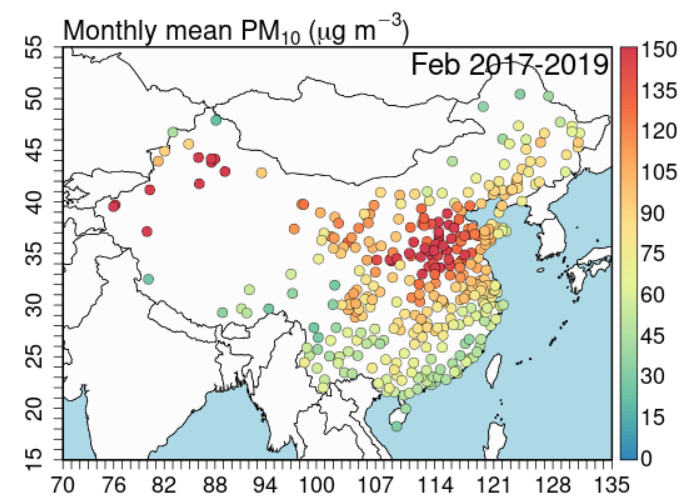

(c)

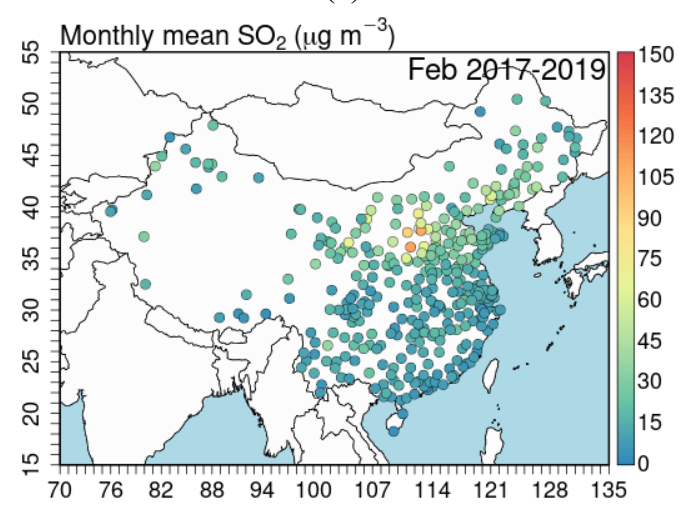

(e)

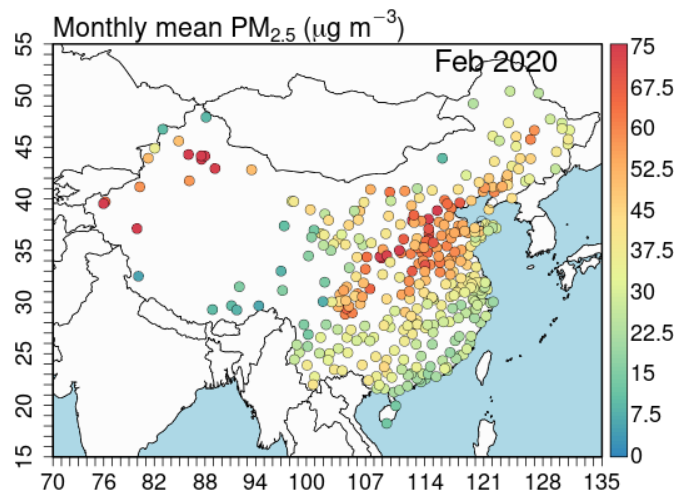

(b)

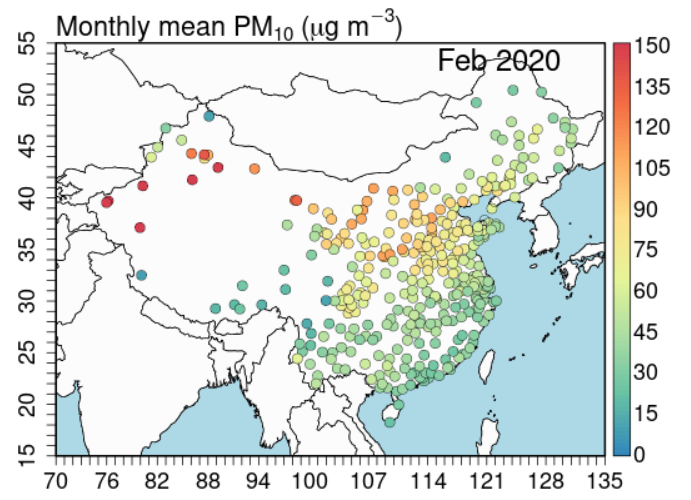

(d)

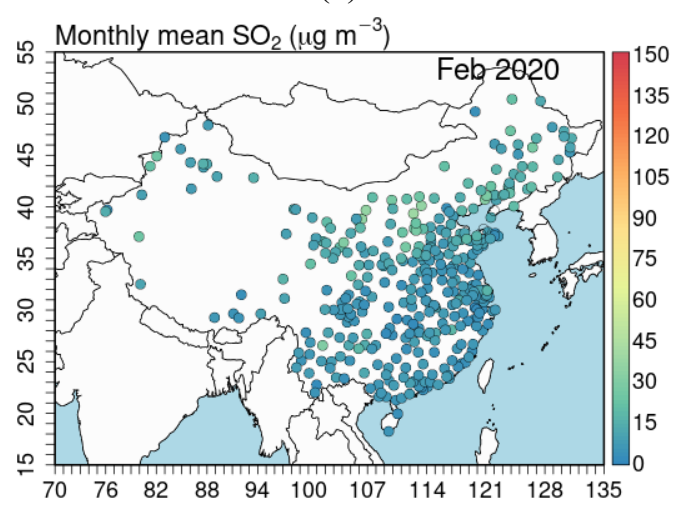

(f)

Fig. 1. Monthly mean concentration of $\mathrm{PM}_{2.5}, \mathrm{PM}_{10}, \mathrm{SO}_{2}, \mathrm{NO}_{2}, \mathrm{O}_{3}$, and $\mathrm{CO}$ in (a, c, e, g, i, k) February 2017-2020 and (b, d, f, h, j, l) February 2020. 


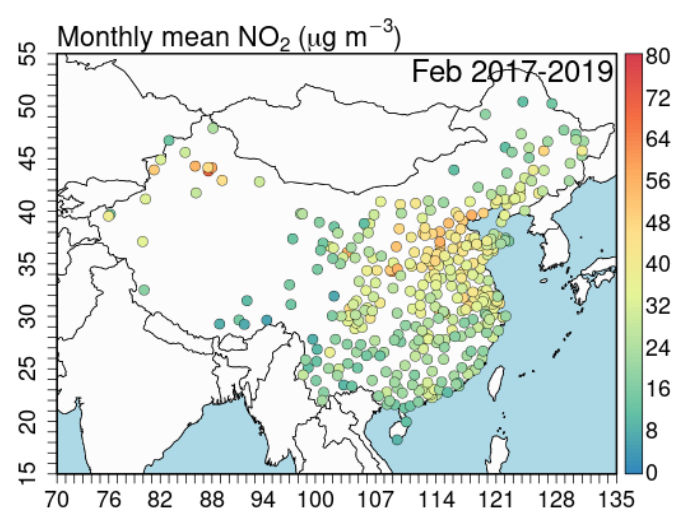

(g)

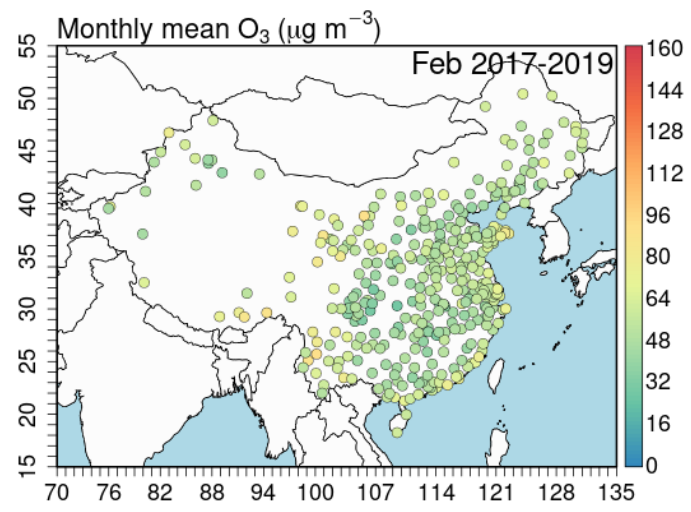

(i)

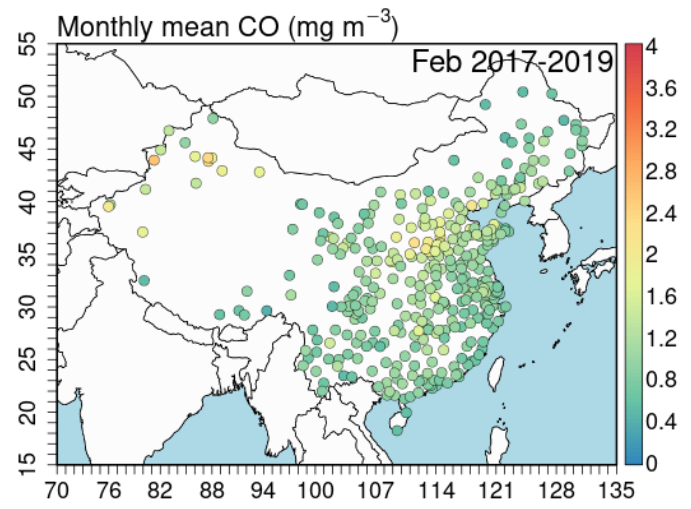

(k)

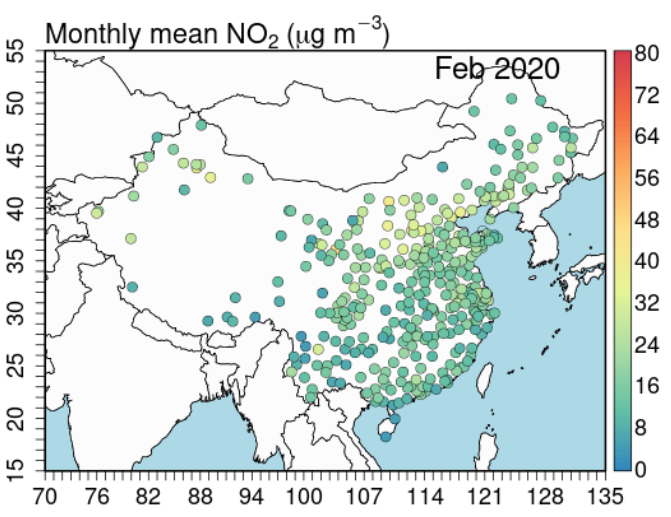

(h)

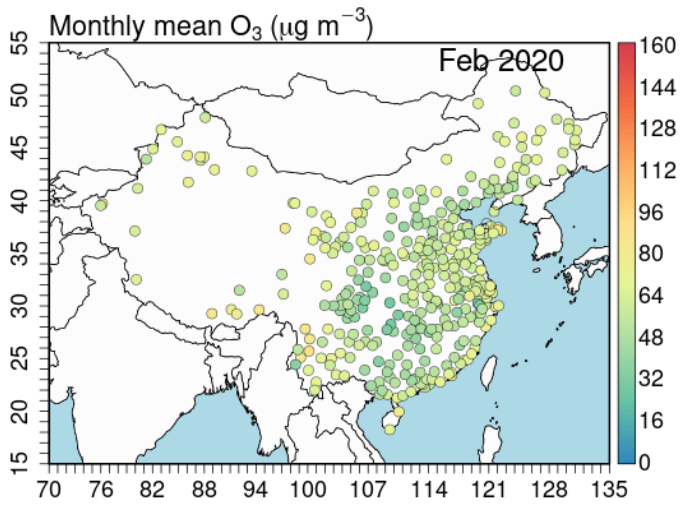

(j)

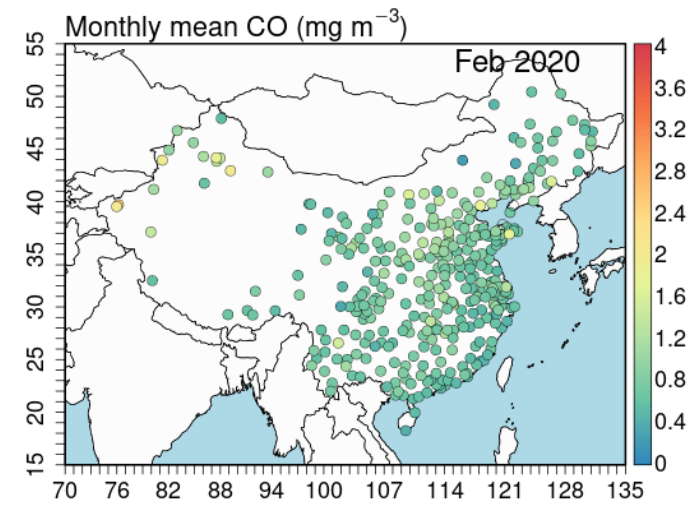

(1)

Fig. 1. (continued).

area showing MEE Level II standard decreases significantly. For $24 \mathrm{~h}$ average $\mathrm{SO}_{2}$, most cities across China meets the WHO and MEE Level I standard and only several cities in Shanxi exceed the WHO and MEE Level I standard in February 2017-2019, and in February 2020 all of the cities including cities in Shanxi meet the standard. $\mathrm{NO}_{2}$ concentrations in Beijing, Tianjin, Hebei, Shanxi, Shaanxi, Shandong Jiangsu and Xinjiang are observed over the WHO and MEE Level I standard concentration in February 20172019 and similar to $\mathrm{SO}_{2}$, all the cities meet the standard in February 2020. $\mathrm{O}_{3}$ concentrations in most part of China generally meet the WHO and MEE Level I standard except some coastal cities and remote region and the spatial characteristic changes little in February 2020. All of CO concentrations across China meet the WHO and MEE Level I standard in February 2017-2019 and in February 2020.

$\mathrm{PM}_{2.5}, \mathrm{PM}_{10}, \mathrm{SO}_{2}, \mathrm{NO}_{2}$ and $\mathrm{CO}$ are concentrated mainly in the north part of China, especially Beijing-Tianjin-Hebei region, where their concentrations in February 2017-2019 are around $100 \mu \mathrm{g} \mathrm{m}^{-3}, 160 \mu \mathrm{g} \mathrm{m}^{-3}, 40 \mu \mathrm{g} \mathrm{m}^{-3}, 60 \mu \mathrm{g} \mathrm{m}^{-3}$, and $1.8 \mathrm{mg} \mathrm{m}^{-3}$, respectively. The spatial distribution of high $\mathrm{O}_{3}$ concentration is contrary to that of $\mathrm{PM}_{2.5}, \mathrm{PM}_{10}, \mathrm{SO}_{2}$, $\mathrm{NO}_{2}$ and $\mathrm{CO}$ because heterogeneous reactions largely reduced surface $\mathrm{O}_{3}$ in polluted regions of China (Li et al., 2018; Li et al., 2019a). The $\mathrm{O}_{3}$ concentration in Beijing-TianjinHebei region is around $60 \mu \mathrm{g} \mathrm{m}^{-3}$ in February 2017-2019. Fig. S1 shows the monthly variation of six major pollutant concentrations in February during 2017 to 2020. From Fig. S1, 
a decrease trend of the concentration of $\mathrm{PM}_{2.5}, \mathrm{PM}_{10}, \mathrm{SO}_{2}$, $\mathrm{NO}_{2}$ and $\mathrm{CO}$ is observed but the decrease trend is mild. While in February 2020, a sharp fall of the concentration of $\mathrm{PM}_{2.5}, \mathrm{PM}_{10}, \mathrm{SO}_{2}, \mathrm{NO}_{2}$ and $\mathrm{CO}$ is observed across the whole country. In Beijing-Tianjin-Hebei region, the $\mathrm{PM}_{2.5}, \mathrm{PM}_{10}$, $\mathrm{SO}_{2}, \mathrm{NO}_{2}$ and $\mathrm{CO}$ concentrations decrease from $100 \mu \mathrm{g} \mathrm{m}^{-}$ ${ }^{3}, 150 \mu \mathrm{g} \mathrm{m}^{-3}, 20 \mu \mathrm{g} \mathrm{m}^{-3}, 40 \mu \mathrm{g} \mathrm{m}^{-3}$, and $1.2 \mathrm{mg} \mathrm{m}^{-3}$ in February 2019 to $70 \mu \mathrm{g} \mathrm{m}^{-3}, 80 \mu \mathrm{g} \mathrm{m}^{-3}, 10 \mu \mathrm{g} \mathrm{m}^{-3}, 25 \mu \mathrm{g} \mathrm{m}^{-3}$, and $0.5 \mathrm{mg}$ $\mathrm{m}^{-3}$ in February 2020, respectively. Such a pollutant reduction is directly related to the strict COVID-19 control measures, because the measures restrict many of the public transport, production and business activities and minimize almost all kinds of social activities that may cause direct contact between people.

To take a further look at air quality variation between months, we compare the $\mathrm{PM}_{2.5}$ concentration from January to April in 2019 and 2020 (Fig. 2). Before the implementation of strict COVID-19 control policy at the beginning of February 2020, an identical spatial distribution of $\mathrm{PM}_{2.5}$ is observed in January 2020 compared to January 2019. The high concentration of $\mathrm{PM}_{2.5}$ in wintertime is mostly due to the large amount of anthropogenic pollutants emitted from heating, industry and traffic and also due to the adverse weather conditions in favor of the massive accumulation of pollutants (Deng et al., 2019; Yang et al., 2019). As time goes, the intensification of atmospheric movements accelerates the diffusion of pollutants and a decrease trend of $\mathrm{PM}_{2.5}$ concentration from January to April is found (Su et al., 2017; Li et al., 2019b). For example in Tianjin, the monthly mean $\mathrm{PM}_{2.5}$ concentrations from January to April 2019 are $81 \mu \mathrm{g} \mathrm{m}^{-3}$,

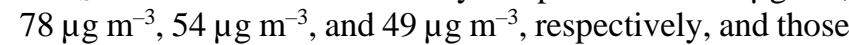
from January to April 2020 are $102 \mu \mathrm{g} \mathrm{m}^{-3}, 62 \mu \mathrm{g} \mathrm{m}^{-3}$, $43 \mu \mathrm{g} \mathrm{m}^{-3}$, and $40 \mu \mathrm{g} \mathrm{m}^{-3}$, respectively. In April 2020, the $\mathrm{PM}_{2.5}$ concentration in most part of China has been significantly decreased compared to 2019. However, $\mathrm{PM}_{2.5}$ concentration in Northeast China met an increase. For example in Harbin, the $\mathrm{PM}_{2.5}$ concentration increases from $36 \mu_{\mathrm{g} \mathrm{m}^{-3}}$ in April 2019 to $91 \mu \mathrm{g} \mathrm{m}^{-3}$ in April 2020. This is mostly due to the slowdown of the COVID-19 control policy, and farmers went out and burned their straw, which led to the significant increase of $\mathrm{PM}_{2.5}$ concentration. The adverse weather condition also contributes to this increase (Li et al., 2016; Yin et al., 2017).

\section{Provincial-scale Analysis of Air Pollutants}

Table 2 shows the decrease ratios of the provincial mean air pollutant concentrations during February to April in 2020 compared to 2019. For $\mathrm{PM}_{2.5}$, an overall decrease ratio of $14 \%$ is observed on national scale. There are 12 provinces showing a decrease ratio over $20 \%$ including Tianjin (20\%), Hebei (29\%), Shanxi (24\%), Shanghai (21\%), Jiangsu (31\%), Zhejiang (22\%), Anhui (30\%), Shandong (29\%), Henan (33\%), Hubei (23\%), Shaanxi (22\%), and Qinghai (22\%). For example in Shanghai, Hubei and Qinghai, the $\mathrm{PM}_{2.5}$ concentrations decrease from $50 \mu \mathrm{g} \mathrm{m}^{-3}, 27 \mu \mathrm{g} \mathrm{m}^{-3}$, and $49 \mu \mathrm{g} \mathrm{m}^{-3}$ in February-April 2019 to $39 \mu \mathrm{g} \mathrm{m}^{-3}, 21 \mu \mathrm{g} \mathrm{m}^{-3}$, and $38 \mu \mathrm{g} \mathrm{m}^{-3}$ in February-April 2020, respectively. Insignificant decrease of $\mathrm{PM}_{2.5}$ concentration (DR $<5 \%$ ) is observed in Jiangxi (5\%), Guangdong (4\%), Guangxi (0\%), Chongqing (5\%), and
Gansu (4\%). And there are three provinces showing a slight increase of $\mathrm{PM}_{2.5}$ concentration including Guizhou (9\%), Yunnan $(6 \%)$, and Xinjiang $(3 \%)$, where the $\mathrm{PM}_{2.5}$ concentrations increase from $27 \mu \mathrm{g} \mathrm{m}^{-3}, 32 \mu \mathrm{g} \mathrm{m}^{-3}$ and $64 \mu \mathrm{g} \mathrm{m}^{-3}$ in February-April 2019 to $30 \mu \mathrm{g} \mathrm{m}^{-3}, 34 \mu \mathrm{g} \mathrm{m}^{-3}$ and $66 \mu \mathrm{g} \mathrm{m}^{-3}$ in February-April 2020.

Similar to $\mathrm{PM}_{2.5}$, the average $\mathrm{PM}_{10}$ concentration decreases by $15 \%$ during February to April 2020 compared to that in 2019. There are 12 provinces showing a decrease ratio over $20 \%$ including Beijing (27\%), Tianjin (28\%), Hebei (30\%), Shanxi $(21 \%)$, Jilin $(25 \%)$, Heilongjiang (28\%), Shanghai (21\%), Jiangsu (27\%), Anhui (22\%), Shandong (30\%), Henan (29\%), and Hubei (25\%). In Hebei, Heilongjiang and Shandong, the $\mathrm{PM}_{10}$ concentrations decrease from $114 \mu \mathrm{g} \mathrm{m}^{-3}$, $73 \mu \mathrm{g} \mathrm{m}^{-3}$, and $109 \mu \mathrm{g} \mathrm{m}^{-3}$ in February-April 2019 to $80 \mu \mathrm{g} \mathrm{m}^{-3}, 52 \mu \mathrm{g} \mathrm{m}^{-3}$, and $77 \mu \mathrm{g} \mathrm{m}^{-3}$ in February-April 2020, respectively. The decrease ratios for $\mathrm{PM}_{10}$ in Beijing, Jilin and Heilongjiang are much larger than those for $\mathrm{PM}_{2.5}$, and this is probably due to the weaker dust transport in 2020 compared to 2019. Five provinces shows an insignificant variation of $\mathrm{PM}_{10}$ concentration, which are Jiangxi (3\%), Guangdong (4\%), Guangxi (2\%), Hainan (4\%), and Guizhou $(2 \%)$. Only Gansu and Xinjiang meet an increase of $\mathrm{PM}_{10}$ concentration by $3 \%$ and $8 \%$, where the $\mathrm{PM}_{10}$ concentrations increase from $84 \mu \mathrm{g} \mathrm{m}^{-3}$ and $86 \mu \mathrm{g} \mathrm{m}^{-3}$ in 2019 to $174 \mu \mathrm{g} \mathrm{m}^{-3}$ and $188 \mu \mathrm{g} \mathrm{m}^{-3}$ in.

The national average decrease ratio for $\mathrm{SO}_{2}$ is $12 \%$. Around half of mainland China (14 of 31 provinces involved in this study) has a decrease ratio between $10 \%$ and $20 \%$. Only 6 provinces show a decrease ratio over $20 \%$, which includes Beijing (28\%), Tianjin (30\%), Hebei (27\%), Shanxi (25\%), Liaoning (27\%), and Shandong (22\%), and their $\mathrm{SO}_{2}$ concentrations decrease from $5 \mu \mathrm{g} \mathrm{m}^{-3}, 12 \mu \mathrm{g} \mathrm{m}^{-3}, 17 \mu \mathrm{g} \mathrm{m}^{-3}$, $27 \mu \mathrm{g} \mathrm{m}^{-3}, 23 \mu \mathrm{g} \mathrm{m}^{-3}$ and $15 \mu \mathrm{g} \mathrm{m}^{-3}$ in February-April 2019 to $4 \mu \mathrm{g} \mathrm{m}^{-3}, 9 \mu \mathrm{g} \mathrm{m}^{-3}, 12 \mu \mathrm{g} \mathrm{m}^{-3}, 20 \mu \mathrm{g} \mathrm{m}^{-3}, 17 \mu \mathrm{g} \mathrm{m}^{-3}$ and $11 \mu \mathrm{g} \mathrm{m}^{-3}$ in February-April 2020, respectively. Five provinces show an increase of $\mathrm{SO}_{2}$ concentrations during COVID-19, and they are Heilongjiang (2\%), Jiangxi (6\%), Hubei (1\%), Guangdong (3\%), and Tibet (32\%). In Jiangxi and Tibet, the $\mathrm{SO}_{2}$ concentrations increase from $11 \mu \mathrm{g} \mathrm{m}^{-3}$ and $5 \mu \mathrm{g} \mathrm{m}^{-3}$ in February-April to $12 \mu \mathrm{g} \mathrm{m}^{-3}$ and $7 \mu \mathrm{g} \mathrm{m}^{-3}$ in February-April 2020. The significant increase of $\mathrm{SO}_{2}$ may result from the biomass burning emission transported from India during the pre-monsoon period (Cong et al., 2015).

The largest decrease ratio $(16 \%)$ on national scales is observed in $\mathrm{NO}_{2}$ concentration. Around $70 \%$ of the country ( 22 of 31 provinces involved in this study) has a decrease ratio between $10 \%$ and $20 \%$. Five provinces show a decrease ratio over $20 \%$ including Beijing (31\%), Hebei (22\%), Shanghai (20\%), Shandong (24\%), and Hubei (32\%), where the $\mathrm{NO}_{2}$ concentrations decrease from $36 \mu \mathrm{g} \mathrm{m}^{-3}, 37 \mu \mathrm{g} \mathrm{m}^{-3}$, $39 \mu \mathrm{g} \mathrm{m}^{-3}, 34 \mu \mathrm{g} \mathrm{m}^{-3}$ and $28 \mu \mathrm{g} \mathrm{m}^{-3}$ in February-April 2019 to $25 \mu \mathrm{g} \mathrm{m}^{-3}, 29 \mu \mathrm{g} \mathrm{m}^{-3}, 31 \mu \mathrm{g} \mathrm{m}^{-3}, 25 \mu \mathrm{g} \mathrm{m}^{-3}$ and $19 \mu \mathrm{g} \mathrm{m}^{-3}$ in February-April 2020, respectively. Only Guangxi and Qinghai show an insignificant decrease of $\mathrm{NO}_{2}$ by $1 \%$ and $5 \%$, respectively, and no increase is observed.

The national scale decrease ratio of $\mathrm{CO}$ is $12 \%$, which is similar to $\mathrm{SO}_{2}$. There are 15 provinces showing a decrease ratio between $10 \%$ and $20 \%$. Six provinces show a decrease 


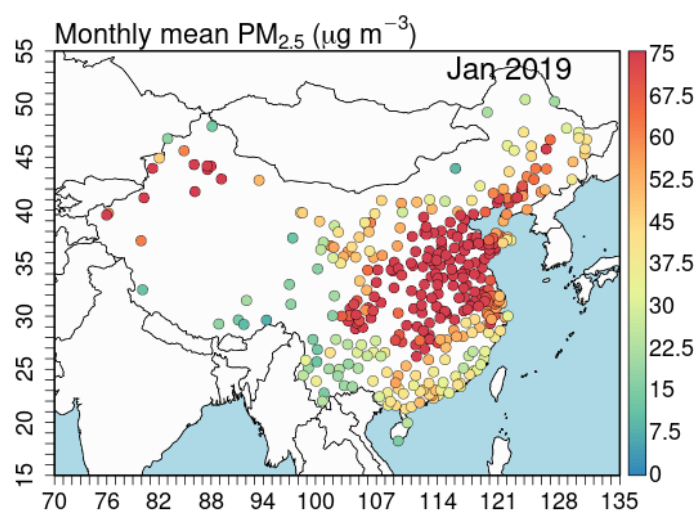

(a)

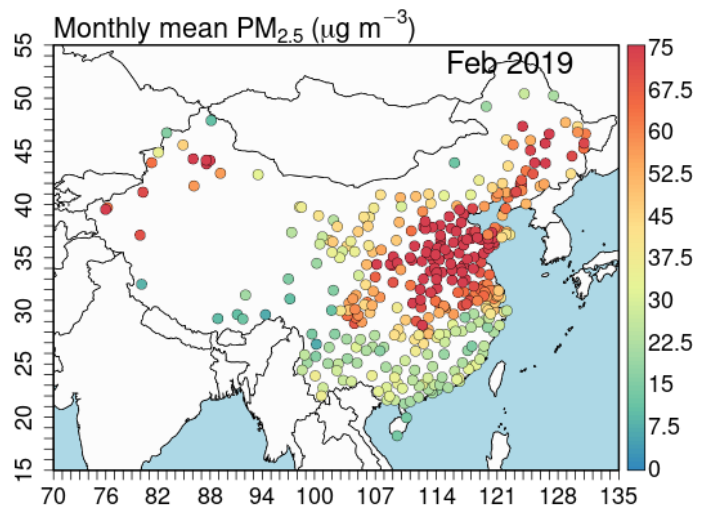

(c)

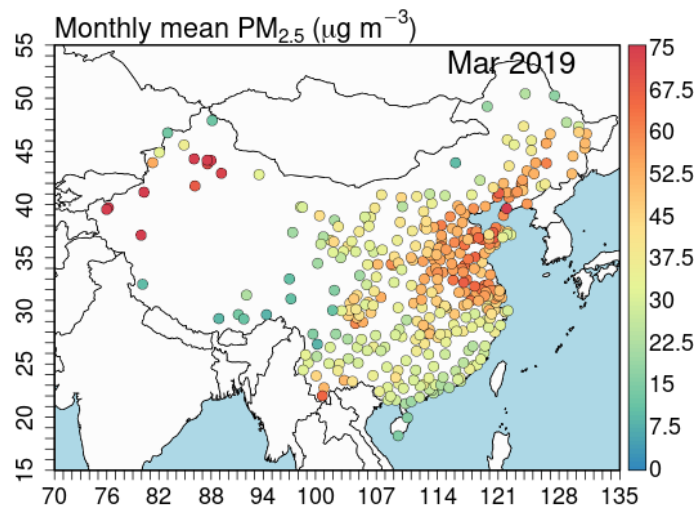

(e)

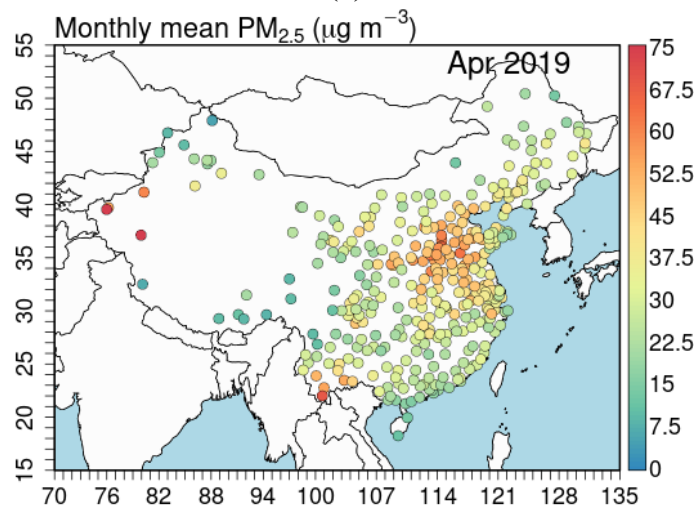

(g)

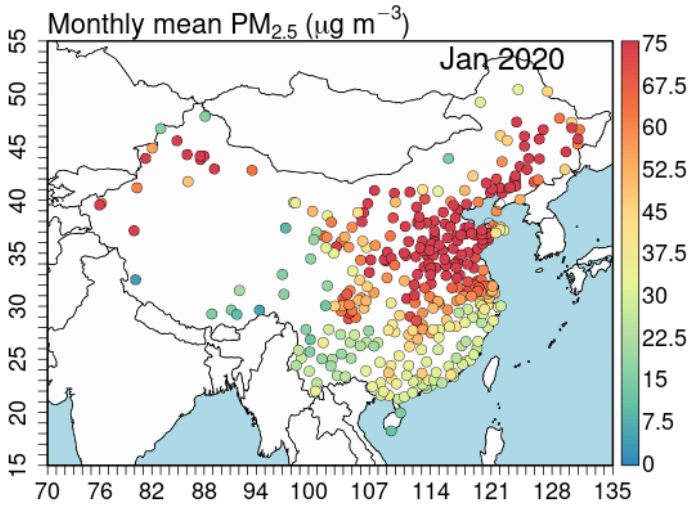

(b)

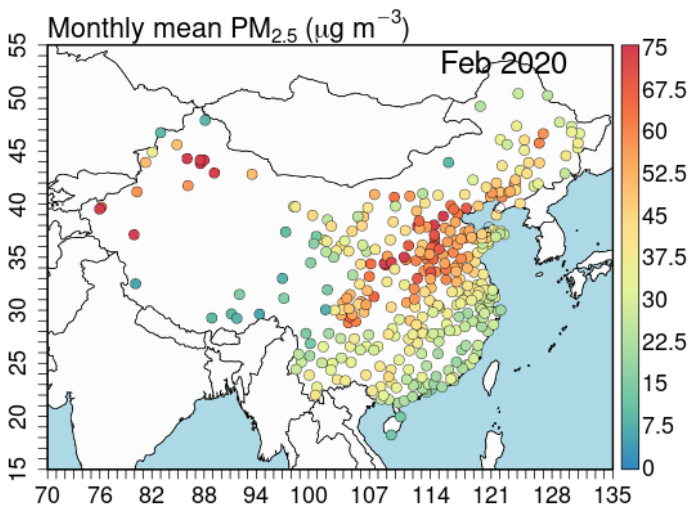

(d)

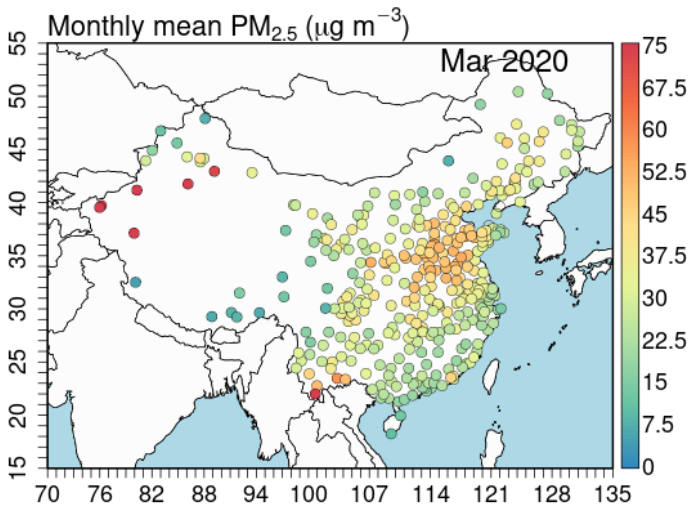

(f)

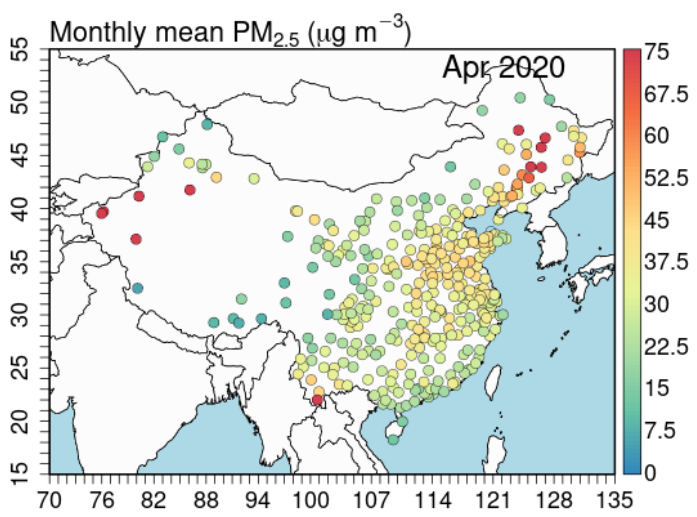

(h)

Fig. 2. Monthly variation of $\mathrm{PM}_{2.5}$ concentration during (a, c, e, g) January-April 2019 and (b, d, f, h) January-April 2020 in mainland China. 
Table 2. Decrease ratio of the provincial mean concentrations of six air pollutants during COVID-19 event (Feb-Apr, 2020) in mainland China.

\begin{tabular}{|c|c|c|c|c|c|c|c|c|c|c|}
\hline \multicolumn{4}{|c|}{ Province } & \multicolumn{7}{|c|}{ Decrease ratio (DR) } \\
\hline & Full name & Abbr. & Code & $\mathrm{PM}_{2.5}$ & $\mathrm{PM}_{10}$ & $\mathrm{SO}_{2}$ & $\mathrm{NO}_{2}$ & $\mathrm{O}_{3}$ & $\mathrm{CO}$ & AQI \\
\hline 1 & Beijing & BJ & 11 & 0.16 & 0.27 & 0.28 & 0.31 & -0.12 & 0.10 & 0.17 \\
\hline 2 & Tianjin & $\mathrm{TJ}$ & 12 & 0.20 & 0.28 & 0.30 & 0.18 & -0.09 & 0.20 & 0.20 \\
\hline 3 & Hebei & $\mathrm{HE}$ & 13 & 0.29 & 0.30 & 0.27 & 0.22 & -0.06 & 0.17 & 0.25 \\
\hline 4 & Shanxi & SX & 14 & 0.24 & 0.21 & 0.25 & 0.13 & -0.01 & 0.23 & 0.19 \\
\hline 5 & Inner Mongolia & IM & 15 & 0.12 & 0.18 & 0.08 & 0.16 & -0.03 & 0.04 & 0.12 \\
\hline 6 & Liaoning & LN & 21 & 0.17 & 0.19 & 0.27 & 0.19 & -0.05 & 0.13 & 0.14 \\
\hline 7 & Jilin & JL & 22 & 0.12 & 0.25 & 0.07 & 0.12 & -0.07 & 0.03 & 0.17 \\
\hline 8 & Heilongjiang & HL & 23 & 0.13 & 0.28 & -0.02 & 0.19 & -0.09 & 0.00 & 0.20 \\
\hline 9 & Shanghai & $\mathrm{SH}$ & 31 & 0.21 & 0.21 & 0.18 & 0.20 & -0.06 & 0.12 & 0.18 \\
\hline 10 & Jiangsu & JS & 32 & 0.31 & 0.27 & 0.15 & 0.18 & -0.11 & 0.15 & 0.25 \\
\hline 11 & Zhejiang & $\mathrm{ZJ}$ & 33 & 0.22 & 0.14 & 0.11 & 0.12 & -0.18 & 0.17 & 0.13 \\
\hline 12 & Anhui & $\mathrm{AH}$ & 34 & 0.30 & 0.22 & 0.14 & 0.18 & -0.13 & 0.17 & 0.23 \\
\hline 13 & Fujian & FJ & 35 & 0.10 & 0.08 & 0.16 & 0.17 & -0.18 & 0.21 & 0.04 \\
\hline 14 & Jiangxi & JX & 36 & 0.05 & 0.03 & -0.06 & 0.06 & -0.30 & 0.18 & 0.02 \\
\hline 15 & Shandong & SD & 37 & 0.29 & 0.30 & 0.22 & 0.24 & -0.03 & 0.20 & 0.25 \\
\hline 16 & Henan & HA & 41 & 0.33 & 0.29 & 0.16 & 0.18 & -0.03 & 0.18 & 0.27 \\
\hline 17 & Hubei & $\mathrm{HB}$ & 42 & 0.23 & 0.25 & -0.01 & 0.32 & -0.22 & 0.03 & 0.20 \\
\hline 18 & Hunan & $\mathrm{HN}$ & 43 & 0.11 & 0.11 & 0.08 & 0.14 & -0.10 & 0.16 & 0.09 \\
\hline 19 & Guangdong & GD & 44 & 0.04 & 0.04 & -0.03 & 0.11 & -0.23 & 0.21 & 0.00 \\
\hline 20 & Guangxi & GX & 45 & 0.00 & 0.02 & 0.06 & 0.01 & -0.23 & 0.16 & -0.01 \\
\hline 21 & Hainan & $\mathrm{HI}$ & 46 & 0.06 & 0.04 & 0.14 & 0.16 & -0.34 & -0.01 & 0.00 \\
\hline 22 & Chongqing & CQ & 50 & 0.05 & 0.08 & 0.12 & 0.12 & 0.08 & 0.07 & 0.05 \\
\hline 23 & Sichuan & $\mathrm{SC}$ & 51 & 0.09 & 0.08 & 0.15 & 0.14 & -0.06 & 0.10 & 0.06 \\
\hline 24 & Guizhou & GZ & 52 & -0.09 & 0.02 & 0.06 & 0.19 & -0.07 & 0.07 & -0.05 \\
\hline 25 & Yunnan & YN & 53 & -0.06 & 0.10 & 0.19 & 0.12 & -0.01 & 0.00 & 0.00 \\
\hline 26 & Tibet & $\mathrm{XZ}$ & 54 & 0.16 & 0.17 & -0.32 & 0.17 & -0.03 & -0.03 & 0.07 \\
\hline 27 & Shaanxi & $\mathrm{SN}$ & 61 & 0.22 & 0.17 & 0.17 & 0.14 & -0.05 & 0.24 & 0.17 \\
\hline 28 & Gansu & GS & 62 & 0.04 & -0.03 & 0.12 & 0.10 & 0.03 & 0.11 & 0.00 \\
\hline 29 & Qinghai & $\mathrm{QH}$ & 63 & 0.22 & 0.14 & 0.14 & 0.05 & 0.02 & 0.10 & 0.10 \\
\hline 30 & Ningxia & NX & 64 & 0.12 & 0.12 & 0.11 & 0.12 & -0.01 & 0.19 & 0.12 \\
\hline 31 & Xinjiang & $\mathrm{XJ}$ & 65 & -0.03 & -0.08 & 0.09 & 0.23 & -0.11 & 0.09 & -0.04 \\
\hline \multicolumn{4}{|c|}{ National average DR } & 0.14 & 0.15 & 0.12 & 0.16 & -0.09 & 0.12 & 0.11 \\
\hline
\end{tabular}

Note: $\mathrm{DR}=1-\mathrm{X}_{2020} / \mathrm{X}_{2019}$, where $\mathrm{X}$ denotes the concentration of air pollutants and the subscript represents the year.

ratio over 20\%, which includes Tianjin (20\%), Shanxi (23\%), Fujian (21\%), Shandong (21\%), Guangdong (21\%), and Shaanxi (24\%). Their CO concentrations decrease from $1.0 \mathrm{mg} \mathrm{m}^{-3}, 1.1 \mathrm{mg} \mathrm{m}^{-3}, 0.7 \mathrm{mg} \mathrm{m}^{-3}, 0.9 \mathrm{mg} \mathrm{m}^{-3}$ and 0.9 $\mathrm{mg} \mathrm{m}^{-3}$ in February-April 2019 to $0.8 \mathrm{mg} \mathrm{m}^{-3}, 0.9 \mathrm{mg} \mathrm{m}^{-3}$, $0.6 \mathrm{mg} \mathrm{m}^{-3}, 0.7 \mathrm{mg} \mathrm{m}^{-3}$ and $0.7 \mathrm{mg} \mathrm{m}^{-3}$ in February-April 2020, respectively. Inner Mongolia, Jilin, Heilongjiang, Hubei, and Yunnan show an insignificant decrease of CO concentration with a decrease ratio of $4 \%, 3 \%, 0,3 \%$ and 0 , respectively. Only Hainan and Tibet show an increase of $\mathrm{CO}$ concentration of $1 \%$ and $3 \%$, respectively, where the $\mathrm{CO}$ concentrations in February-April 2020 are $0.5 \mathrm{mg} \mathrm{m}^{-3}$ and $0.6 \mathrm{mg} \mathrm{m}^{-3}$.

The variation of $\mathrm{O}_{3}$ concentration is generally the opposite of other pollutants and it shows an increase of $9 \%$ on national scale. There are 28 provinces show an increase of $\mathrm{O}_{3}$ concentration. Five provinces have an increase ratio over $20 \%$ including Jiangxi (30\%), Hubei (22\%), Guangdong $(23 \%)$, Guangxi $(23 \%)$, and Hainan $(34 \%)$, where the $\mathrm{O}_{3}$ concentrations increase from $55 \mu \mathrm{g} \mathrm{m}^{-3}, 54 \mu \mathrm{g} \mathrm{m}^{-3}, 48 \mu \mathrm{g} \mathrm{m}^{-3}$,
$40 \mu \mathrm{g} \mathrm{m}^{-3}$ and $48 \mu \mathrm{g} \mathrm{m}^{-3}$ in February-April 2019 to $65 \mu \mathrm{g} \mathrm{m}^{-3}$, $66 \mu \mathrm{g} \mathrm{m}^{-3}, 59 \mu \mathrm{g} \mathrm{m}^{-3}, 48 \mu \mathrm{g} \mathrm{m}^{-3}$ and $64 \mu \mathrm{g} \mathrm{m}^{-3}$ in FebruaryApril 2020, respectively. And nine provinces show an insignificant increase of $\mathrm{O}_{3}$ concentration $(<5 \%)$, which includes Shanxi (1\%), Inner Mongolia (3\%), Liaoning (5\%), Shandong (3\%), Henan (3\%), Yunnan (1\%), Tibet (3\%), Shaanxi (5\%), and Ningxia (1\%). Three provinces meet a decrease of $\mathrm{O}_{3}$ concentration including Chongqing (8\%), Gansu (3\%), and Qinghai (2\%), where the $\mathrm{O}_{3}$ concentrations decrease from $45 \mu \mathrm{g} \mathrm{m}^{-3}, 73 \mu \mathrm{g} \mathrm{m}^{-3}$ and $79 \mu \mathrm{g} \mathrm{m}^{-3}$ in 2019 to $42 \mu \mathrm{g} \mathrm{m}^{-3}, 71 \mu \mathrm{g} \mathrm{m}^{-3}$ and $77 \mu \mathrm{g} \mathrm{m}^{-3}$ in 2020 , respectively.

AQI decreases by $11 \%$ on national scale during February to April 2020 compared to 2019. Large decrease ratios (> 20\%) are found in Tianijn (20\%), Hebei (25\%), Heilongjiang (20\%), Jiangsu (25\%), Anhui (23\%), Shandong $(25 \%)$, Henan $(27 \%)$ and Hubei $(20 \%)$, where the AQI decreases from 93, 96, 67, 77, 81, 92, 109, and 73 in 2019 to $75,72,54,58,62,69,80$, and 59 in 2020 , respectively. There are 10 provinces having a decrease ratio between $10 \%$ and $20 \%$ and 7 provinces having an insignificant decrease of 
AQI (< 5\%). Guangxi, Guizhou, and Xinjiang show an increase of AQI by $1 \%, 5 \%$ and $4 \%$, respectively. The variation of $\mathrm{AQI}$ is generally in consistent with that of $\mathrm{PM}_{2.5}$, $\mathrm{PM}_{10}, \mathrm{SO}_{2}, \mathrm{NO}_{2}$ and $\mathrm{CO}$, while the opposite of $\mathrm{O}_{3}$.

In general, insignificant variation of pollutants are mainly found in Fujian, Jiangxi, Guangdong, Guangxi, Hainan, Guizhou, Yunnan, Gansu, and Xinjiang, where the seasonal mean concentration of major pollutants are generally low, while significant variation of pollutants are mainly observed in Beijing, Tianjin, Hebei, Shandong, Shanghai, Anhui, Jinagsu, Henan, and Hubei, where the seasonal mean concentration of major pollutants are generally high. Thus, the strict COVID-19 control policy can effectively improve the air quality in northeast and inland provinces where previous air quality was poor, while the effect of the COVID-19 policy is less significant in southeast coastal and western provinces where previous air quality was good. On the whole, twenty six provinces $(84 \%)$ meet an AQI improvement due to COVID-19 control policy.

\section{Diurnal Variation of PM2.5}

Fig. 3 shows the diurnal variation of $\mathrm{PM}_{2.5}$ concentrations

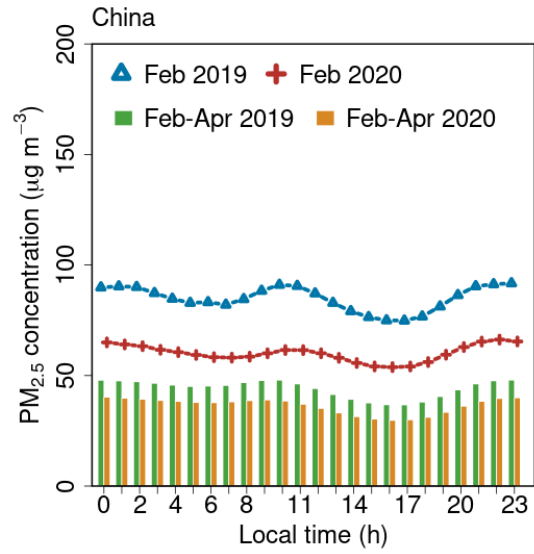

(a)

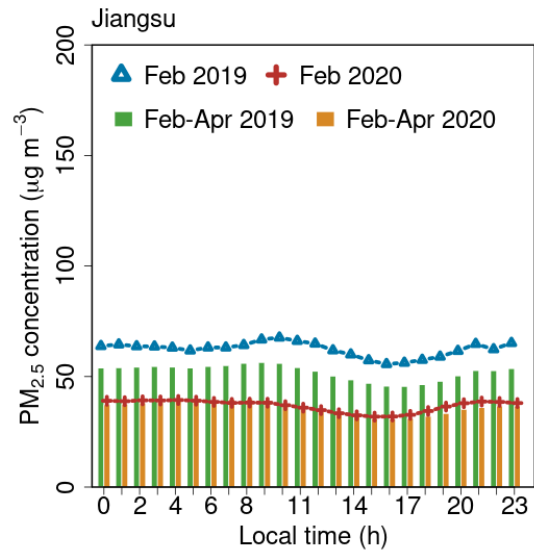

(d)

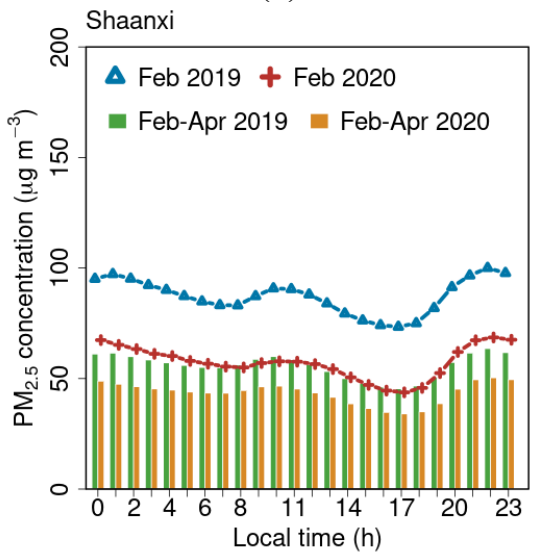

(g)

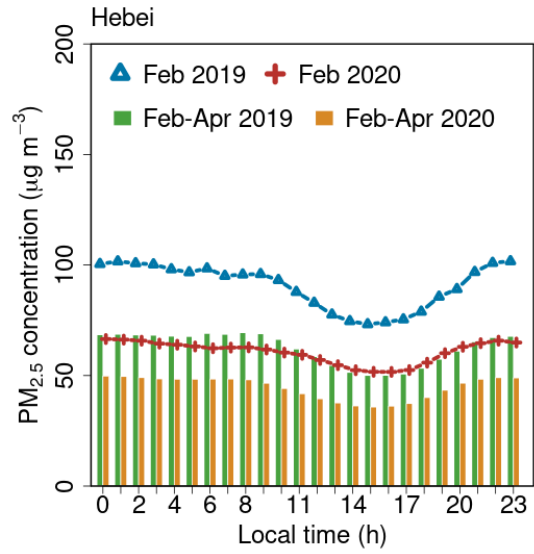

(b)

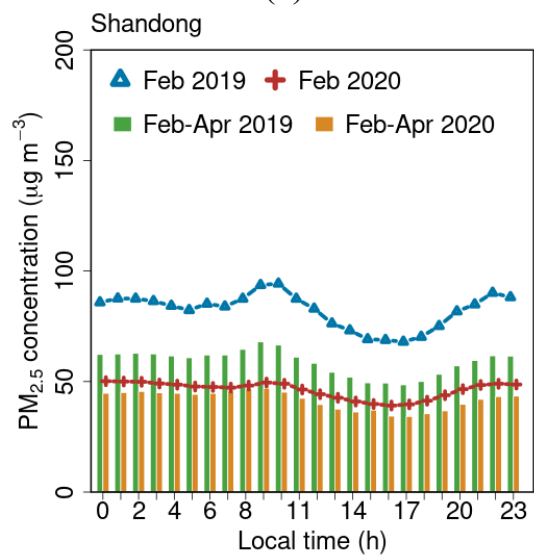

(e)

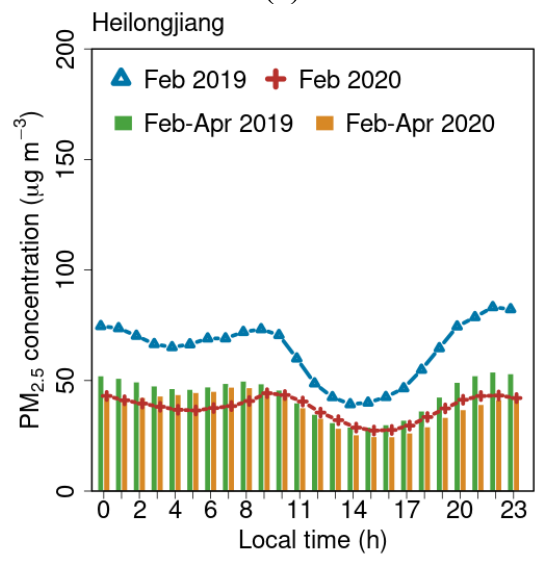

(h)

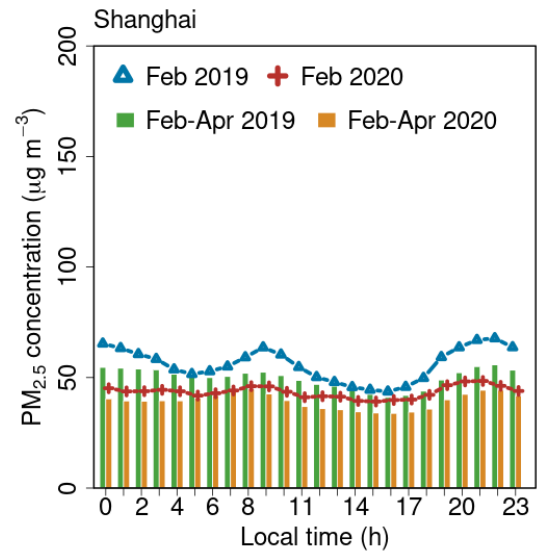

(c)

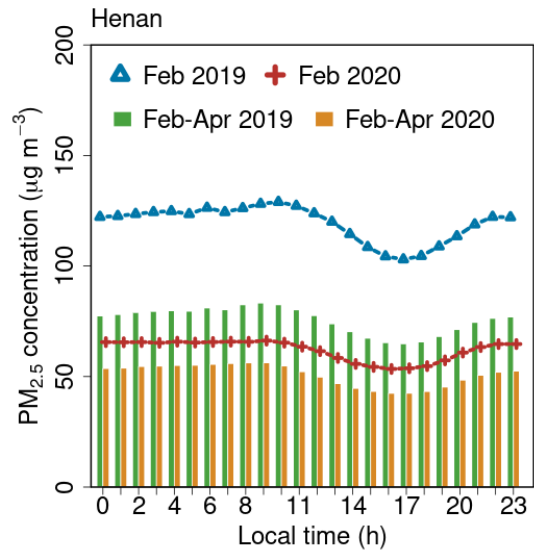

(f)

Fig. 3. Diurnal variation of $\mathrm{PM}_{2.5}$ concentration in 2019 and 2020 on (a) national scale and (b-h) provincial scale. 
in 2019 and 2020, and Fig. S2 presents results of the rest 24 provinces. In general, $\mathrm{PM}_{2.5}$ concentrations vary with time and region. On national scale, the lowest $\mathrm{PM}_{2.5}$ concentrations $\left(55 \mathrm{\mu g} \mathrm{m}^{-3}\right.$ in February 2020) are distributed in the afternoon while the peak values $\left(70 \mu \mathrm{g} \mathrm{m}^{-3}\right)$ are generally distributed in the morning and evening. Such a variation is mostly observed in provinces like Hebei, Shandong, Henan, Shaanxi, and Heilongjiang, where the daily mean $\mathrm{PM}_{2.5}$ concentration is generally high $\left(>50 \mu \mathrm{g} \mathrm{m}^{-3}\right.$ ). However, the variation is less obvious in provinces like Guangdong and Zhejiang, where the daily mean $\mathrm{PM}_{2.5}$ concentration is low $\left(<30 \mu \mathrm{g} \mathrm{m}^{-3}\right)$. Although strict COVID-19 control policy is implemented, the diurnal variation of $\mathrm{PM}_{2.5}$ remains unchanged. The low $\mathrm{PM}_{2.5}$ concentration in the afternoon is generally due to that the height of boundary layer in the afternoon is the highest of the day, so the concentration is correspondingly decreased to the lowest value (Guo et al., 2017; Li et al., 2019b). When temperature decreases in the evening, the height of boundary layer decreases and accordingly the concentration increases to the peak value. The concentration increase in the morning is mainly due to the rapid increase of aerosol emissions and slow increase of boundary layer height (Guo et al., 2017).

\section{Association between PM2.5 Concentration and COVID-19 Infections}

Fig. 4 shows the time series variation of new COVID-19 cases and the total confirmed cases. To better discuss the correlation between $\mathrm{PM}_{2.5}$ concentration and COVID-19 infections, correlations in three time ranges are considered, which are the lockdown (1 February-29 February), main phase (January 20-29 February), and the whole studying period (January 1-30 April). The lockdown refers to the period with nationwide strict COVID-19 control policy, and the main phase refers to the period of the sharp increase of COVID-19 infections. Table 3 shows the statistical results between $\mathrm{PM}_{2.5}$ concentration and the COVID-19 infections in mainland China. The correlations of fixed effect of $\mathrm{PM}_{2.5}$ concentration for lockdown, main phase and the whole studying period are $0.279,0.200$, and 0.199 respectively. Most of the estimated slopes and intercepts have a p-value less than 0.001 and only the estimated slope in main phase has a p-value less than 0.01 . The small $\mathrm{p}$-value $(<0.05)$ and the positive correlations observed in different time ranges indicate that $\mathrm{PM}_{2.5}$ is positively correlated to the new COVID-19 cases, which agrees with the early COVID-19 findings (Xie and Zhu, 2020). To minimize the risk of

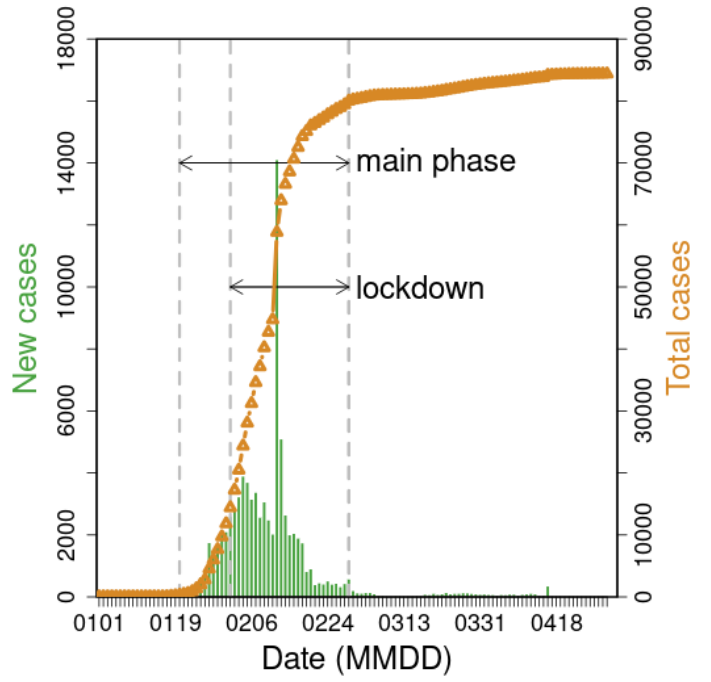

Fig. 4. Time series variation of COVID-19 cases in mainland China. Lockdown refers to the period with nationwide strict control policy, and main phase refers to period with sharp increase of total cases.

aerosol transmission, it is not suggested to go out in severe $\mathrm{PM}_{2.5}$ pollution days. And according to the diurnal variation of $\mathrm{PM}_{2.5}$ concentration (Fig. 3), it's better to go out in the afternoon because $\mathrm{PM}_{2.5}$ concentration in the afternoon is generally the lowest of the day. Also, try to avoid going out in late morning and evening because $\mathrm{PM}_{2.5}$ concentration is increasing thus the risk of infections increases.

\section{CONCLUSIONS}

This study evaluates the influence of nationwide lockdown on air quality during COVID-19 as well as the association between $\mathrm{PM}_{2.5}$ and COVID-19 infections in mainland China. Data from 366 air quality monitoring stations during January to April in 2017-2020 are used to investigate the air quality improvement. Compared to 2019, a national scale decrease of $14 \%, 15 \%, 12 \%, 16 \%$ and $12 \%$ is observed for $\mathrm{PM}_{2.5}, \mathrm{PM}_{10}, \mathrm{SO}_{2}, \mathrm{NO}_{2}$ and $\mathrm{CO}$, respectively, while $\mathrm{O}_{3}$ has a slight increase of $9 \%$. The diurnal variation of particulate matter concentrations changes less during COVID-19. Lowest $\mathrm{PM}_{2.5}$ concentrations are mainly distributed in the afternoon while high concentrations are witnessed in the morning and evening. Correlation analysis shows that positive correlations between $\mathrm{PM}_{2.5}$ concentration and new

Table 3. Statistical results of the fixed effects of $\mathrm{PM}_{2.5}$ concentration on daily COVID-19 infections in mainland China.

\begin{tabular}{|c|c|c|c|c|c|c|c|c|}
\hline \multirow{2}{*}{ Period } & \multirow{2}{*}{$\mathrm{N}$} & \multicolumn{3}{|c|}{ Slope } & \multicolumn{3}{|c|}{ Intercept } & \multirow{2}{*}{$\begin{array}{l}\text { Correlation of } \\
\text { fixed effect }\end{array}$} \\
\hline & & Estimate & Std. Error & $\mathrm{t}$ value & Estimate & Std. Error & $\mathrm{t}$ value & \\
\hline $\begin{array}{l}\text { Lockdown } \\
\text { Feb 01-Feb } 29\end{array}$ & 2630 & $0.068 * * *$ & 0.013 & 5.218 & $0.331 * * *$ & 0.022 & 14.748 & 0.279 \\
\hline $\begin{array}{l}\text { Main phase } \\
\text { Jan } 20-\text { Feb } 29\end{array}$ & 4047 & $0.027 * *$ & 0.009 & 3.114 & $0.309 * * *$ & 0.020 & 15.360 & 0.200 \\
\hline $\begin{array}{l}\text { Studying period } \\
\text { Jan 01-Apr } 30\end{array}$ & 4351 & $0.029 * * *$ & 0.009 & 3.193 & $0.304 * * *$ & 0.019 & 16.256 & 0.199 \\
\hline
\end{tabular}

$* \mathrm{p}<0.05 ; * * \mathrm{p}<0.01 ; * * * \mathrm{p}<0.001$. 
COVID-19 infections are observed in different time ranges. The preliminary results in this study gives the following suggestions to the public to avoid the potential aerosol transmission of COVID-19:

(1) do not go out in heavy polluted days and try to minimize the exposure time in high $\mathrm{PM}_{2.5}$ concentration environment;

(2) better to go out in the afternoon, because $\mathrm{PM}_{2.5}$ concentration is the lowest of a day;

(3) avoid going out in late morning and evening, because the $\mathrm{PM}_{2.5}$ concentration is increasing.

As for policy maker, the increase of $\mathrm{PM}_{2.5}$ concentration due to human activities should be avoided, limited or scheduled during this sensitive period to minimize the risk of aerosol transmission of COVID-19. Since the diurnal variation of $\mathrm{PM}_{2.5}$ concentration may vary with countries and regions, a further study is planned to suggest a more proper time range for people to go outdoors in other part of world. Also, further studies are needed to understand the detailed knowledge of aerosol transmission of COVID-19 so that more reliable and effective measures can be taken to stop the pandemic.

\section{ACKNOWLEDGMENTS}

This study is supported by the National Natural Science Foundation of China (52041601). We thank the China's National Environmental Monitoring Center and the Wuhan2019-nCov Github project for kindly providing the air quality and COVID-19 infection data.

\section{SUPPLEMENTARY MATERIAL}

Supplementary data associated with this article can be found in the online version at http://www.aaqr.org.

\section{REFERENCES}

Cong, Z., Kang, S., Kawamura, K., Liu, B., Xin, W., Wang, Z., Gao, S. and Fu, P. (2015). Carbonaceous aerosols on the south edge of the Tibetan Plateau: Concentrations, seasonality and sources. Atmos. Chem. Phys. 15: 15731584. https://doi.org/10.5194/acp-15-1573-2015

Deng, X., Cao, W., Huo, Y., Yang, G., Yu, C., He, D., Deng, W., Fu, W., Ding, H., Zhai, J., Cheng, L. and Zhao, X. (2019). Meteorological conditions during a severe, prolonged regional heavy air pollution episode in eastern China from December 2016 to January 2017. Theor. Appl. Clim. 135: 1105-1122. https://doi.org/10.1007/s00704018-2426-4

Dong, R., Fisman, R., Wang, Y. and Xu, N. (2019). Air pollution, affect, and forecasting bias: Evidence from Chinese financial analysts. J. Financ. Econ. https://doi.org/ 10.1016/j.jfineco.2019.12.004

Guo, J., Xia, F., Zhang, Y., Liu, H., Li, J., Lou, M., He, J., Yan, Y., Wang, F., Min, M. and Zhai, P. (2017). Impact of diurnal variability and meteorological factors on the $\mathrm{PM}_{2.5}$ - AOD relationship: Implications for $\mathrm{PM}_{2.5}$ remote sensing. Environ. Pollut. 221: 94-104. https://doi.org/10. 1016/j.envpol.2016.11.043
Guo, Y.R., Cao, Q.D., Hong, Z.S., Tan, Y.Y., Chen, S.D., Jin, H.J., Tan, K.S., Wang, D.Y. and Yan, Y. (2020). The origin, transmission and clinical therapies on coronavirus disease 2019 (COVID-19) outbreak - An update on the status. Mil. Med. Res. 7: 11. https://doi.org/10.1186/s407 79-020-00240-0

Hayes, R.B., Lim, C., Zhang, Y., Cromar, K., Shao, Y., Reynolds, H.R., Silverman, D.T., Jones, R.R., Park, Y., Jerrett, M., Ahn, J. and Thurston, G.D. (2019). PM$_{2.5}$ air pollution and cause-specific cardiovascular disease mortality. Int. J. Epidemiol. 49: 25-35. https://doi.org/10. 1093/ije/dyz114

Kraemer, M.U.G., Yang, C.H., Gutierrez, B., Wu, C.H., Klein, B., Pigott, D.M., du Plessis, L., Faria, N.R., Li, R., Hanage, W.P., Brownstein, J.S., Layan, M., Vespignani, A., Tian, H., Dye, C., Pybus, O.G. and Scarpino, S.V. (2020). The effect of human mobility and control measures on the COVID-19 epidemic in China. Science 368: 493-497. https://doi.org/10.1126/science.abb4218

Li, J., Li, Y., Bo, Y. and Xie, S. (2016). High-resolution historical emission inventories of crop residue burning in fields in China for the period 1990-2013. Atmos. Environ. 138: 152-161. https://doi.org/10.1016/j.atmosenv.2016. 05.002

Li, J., Chen, X., Wang, Z., Du, H., Yang, W., Sun, Y., Hu, B., Li, J., Wang, W., Wang, T., Fu, P. and Huang, H. (2018). Radiative and heterogeneous chemical effects of aerosols on ozone and inorganic aerosols over East Asia. Sci. Total Environ. 622-623: 1327-1342. https://doi.org/ 10.1016/j.scitotenv.2017.12.041

Li, K., Jacob, D.J., Liao, H., Shen, L., Zhang, Q. and Bates, K.H. (2019a). Anthropogenic drivers of 2013-2017 trends in summer surface ozone in China. PNAS 116: 422-427. https://doi.org/10.1073/pnas.1812168116

Li, R., Wang, Z., Cui, L., Fu, H., Zhang, L., Kong, L., Chen, W. and Chen, J. (2019b). Air pollution characteristics in China during 2015-2016: Spatiotemporal variations and key meteorological factors. Sci. Total Environ. 648: 902915. https://doi.org/10.1016/j.scitotenv.2018.08.181

Ma, Y., Zhao, Y., Liu, J., He, X., Wang, B., Fu, S., Yan, J., Niu, J., Zhou, J. and Luo, B. (2020). Effects of temperature variation and humidity on the death of COVID-19 in Wuhan, China. Sci. Total Environ. 724: 138226. https://doi.org/10.1016/j.scitotenv.2020.138226

McGuinn, L.A., Schneider, A., McGarrah, R.W., WardCaviness, C., Neas, L.M., Di, Q., Schwartz, J., Hauser, E.R., Kraus, W.E., Cascio, W.E., Diaz-Sanchez, D. and Devlin, R.B. (2019). Association of long-term $\mathrm{PM}_{2.5}$ exposure with traditional and novel lipid measures related to cardiovascular disease risk. Environ. Int. 122: 193200. https://doi.org/10.1016/j.envint.2018.11.001

Schraufnagel, D.E., Balmes, J.R., Cowl, C.T., De Matteis, S., Jung, S.H., Mortimer, K., Perez-Padilla, R., Rice, M.B., Riojas-Rodriguez, H., Sood, A., Thurston, G.D., To, T., Vanker, A. and Wuebbles, D.J. (2019). Air pollution and noncommunicable diseases: A review by the Forum of International Respiratory Societies' Environmental Committee, Part 2: Air pollution and organ systems. Chest 155: 417-426. https://doi.org/10.106/j.chest.2018.10.041 
Shereen, M.A., Khan, S., Kazmi, A., Bashir, N. and Siddique, R. (2020). COVID-19 infection: Origin, transmission, and characteristics of human coronaviruses. J. Adv. Res. 24: 91-98. https://doi.org/10.1016/j.jare.202 0.03 .005

Su, X., Wang, Q., Li, Z., Calvello, M., Esposito, F., Pavese, G., Lin, M., Cao, J., Zhou, C., Li, D. and Xu, H. (2017). Regional transport of anthropogenic pollution and dust aerosols in spring to Tianjin - A coastal megacity in China. Sci. Total Environ. 584-585: 381-392. https://doi. org/10.1016/j.scitotenv.2017.01.016

Wang, J. and Du, G. (2020). COVID-19 may transmit through aerosol. Ir. J. Med. Sci. 24: 1-2. https://doi.org/1 0.1007\%2Fs 11845-020-02218-2

Xie, J. and Zhu, Y. (2020). Association between ambient temperature and COVID-19 infection in 122 cities from China. Sci. Total Environ. 724: 138201. https://doi.org/10. 1016/j.scitotenv.2020.138201

Xu, K., Cui, K., Young, L.H., Hsieh, Y.K., Wang, Y.F., Zhang, J. and Wan, S. (2020a). Impact of the COVID-19 event on air quality in central China. Aerosol Air Qual. Res. 20: 915-929. https://doi.org/10.4209/aaqr.2020.04.0150

Xu, K., Cui, K., Young, L.H., Wang, Y.F., Hsieh, Y.K.,
Wan, S. and Zhang, J. (2020b). Air quality index, indicatory air pollutants and impact of COVID-19 event on the air quality near central China. Aerosol Air Qual. Res. 20: 1204-1221. https://doi.org/10.4209/aaqr.2020.0 4.0139

Yang, J., Ji, Z., Kang, S., Zhang, Q., Chen, X. and Lee, S.Y. (2019). Spatiotemporal variations of air pollutants in western China and their relationship to meteorological factors and emission sources. Environ. Pollut. 254: 112952. https://doi.org/10.1016/j.envpol.2019.07.120

Yin, S., Wang, X., Xiao, Y., Tani, H., Zhong, G. and Sun, Z. (2017). Study on spatial distribution of crop residue burning and $\mathrm{PM}_{2.5}$ change in China. Environ. Pollut. 220: 204-221. https://doi.org/10.1016/j.envpol.2016.09.040

Zheng, Y.Y., Ma, Y.T., Zhang, J.Y. and Xie, X. (2020). COVID-19 and the cardiovascular system. Nat. Rev. Cardiol. 17: 259-260. https://doi.org/10.1038/s41569-0200360-5 